INTERNATIONAL JOURNAL OF MULTIDISCIPLINARY RESEARCh AND ANALySis

ISSN(print): 2643-9840, ISSN(online): 2643-9875

Volume 03 Issue 12 December 2020

DOI: 10.47191/ijmra/v3-i12-15, Impact Factor: 5.522

Page No.- 358-364

\title{
Evaluation the Supply Chain Management in the Accounting Service Firms in Hanoi
}

\author{
Cam Van Bui ${ }^{1}$, Son Tung $\mathrm{Ha}^{2}$, Phan Hoa Le ${ }^{3}$, Manh Linh Tran ${ }^{4}$, Duc Dinh Truong ${ }^{5}$ \\ 1,2,3,4 National Economics University, Vietnam \\ ${ }^{5}$ University of Labor and Social Affairs, Vietnam
}

\begin{abstract}
The accountants in the accounting service firms in Hanoi all have a high level of education, an understanding of high socio-economic knowledge and a certain level of training can definitely involve in supply chain management (SCM) in the accounting service firms. This research was conducted to measure the SCM in the accounting service firms in Hanoi. Data were collected through a survey with 135 accountants and businesses employee from accounting service firms in Hanoi. With this data, we have used descriptive statistics, Cronbach's Alpha analysis to identify and measure sixteen (16) attributes of SCM in the accounting service firms in Hanoi. The results showed that SCM is highly appreciated by respondents. Based on the findings, some recommendations are given to improve SCM in the accounting service firms in Hanoi.
\end{abstract}

Keywords: SCM, custermer, supplier, information share, information quality

JEL code: M10, M40, M29

\section{Introduction}

Supply chain management (SCM) is one of the highly effective new management methods for enterprises. According to Cigolini et al (2004), the mainly current competition is in supply chains rather than between individual enterprises. The SCM contains strategic and tactical issues, cooperation and technically scientific applications (Vaart \& Donk, 2008).

SCM helps businesses to improve partnerships with suppliers (Chen \& Paulraj, 2004; Chin et al., 2012), improve relationships and increase customer service (Chin et al., 2012), improve distribution process, increase the ability of on-time delivery and reduce delivery times (Chen \& Paulraj, 2004).

The accounting service firms in Hanoi provide accounting services. These companies play an important role in assisting and advising investors and firms on the laws, regimes and financial and accounting institutions of State; guiding firms to make vouchers, bookkeeping, tax calculation and financial statements. However, most of accounting service firms were young, newly established, poor facilities, little corporate governance experience, having to compete fiercely with the larger force, which were unregistered units and individuals but still practiced in accounting service business. A number of companies that managed service quality were not scientific and had not fully issued the company's process documents (Mai, 2013). Therefore, accounting services firms need to develop comprehensively, with special attention to improve supply chain in order to enhance service quality; resulting in business efficiency, maintaining and improving competitive advantage.

\section{Literature Review \\ SCM definition}

Lambert et al. (1998) argue that SCM is the integration of important business processes from the end consumers through the original suppliers that provide value added products, services and information to customers and other stakeholders.

Stock \& Boyer (2009) argued that network management within a company and among enterprises have linked together. Business units include material suppliers, purchasing companies, manufacturers, transportation, marketing companies and related systems. These will facilitate the transfer and the reversal of the flow of materials, services, finance and information from the producer to the end customer with the benefits of value increasing, maximizing profit, achieving efficiency and customer satisfaction. 


\section{Evaluation the Supply Chain Management in the Accounting Service Firms in Hanoi}

\section{SCM performance}

Performance measurement can be defined as the process of quantifying the efficiency and effectiveness of action, including quality, time, cost, response and flexibility (Neely et al. (1995). This result is similar to that of Beamon (1999).

SCM includes activities that can facilitate the transportation of goods and information flows from material suppliers to the end customers. It helps to improve the relationship between suppliers and customers to produce a high quality product at a lower cost. This helps to gain a competitive advantage in the global market (Chuang \& Shaw, 2005).

According to Sandhu et al (2013), supply chain management includes 7 dimensions: strategic supplier partnership, customer relationship, information sharing, information quality, postponement, agreed vision and goals and risk and award sharing.

\section{SCM practices}

Donlon (1996) started a revolution in research on SCM practices by arguing that SCM practices involve suppliers cooperation, external forces usage, efforts to reduce production cycles, continuous production process and information sharing. Tan et al. (1998) argue that SCM practices include procurement, quality management and customer relationship management. Tan (2001) expands SCM practices to include the integration in the material flow-related chain, the information flow between the suppliers, the manufacturers and the customers, and the implementation of delay and mass production. Yap \& Tan (2012) affirms that SCM practices include the following factors: chain integration, chain characteristics, information sharing, customer relationship management, quality management and just-in-time production capability.

Recently, there are increasing researches on SCM in Vietnam such as: Vo Thi Thanh Loc and Nguyen Phu Son (2011), Ha Van Hoi (2012), Le Thi Minh Hang (2016) ... However, previous researches have focused on the value chain or the current situation of SCM in a specific company or industry. There is lack of researches on SCM of accounting services firms.

\section{Methodology}

The sample is the accouting service firms in Hanoi. We send surveys to accouting service firms in Hanoi through email and by post or in person. In a 5-weeks period we collect data with firms that have been sent us by making phone calls or visiting in person. We gathered about 150 questionnaires to analyze the data. We choose accouting service firms in Hanoi because Hanoi is the leading economic center of Vietnam.

Inheriting results from previous studies, we identify SCM in the Accounting service firms in Hanoi included 16 attributes (indicators and scales) (see table 1).

Table 1. Attributes of SCM in the Accounting service firms

\begin{tabular}{|l|l|l|}
\hline Code & Scale & \multicolumn{2}{l|}{ Sources } \\
\hline Strategic supplier partnership (SSP) & $\begin{array}{l}\text { Accounting service firms consider quality as one of } \\
\text { the important factors in selecting suppliers }\end{array}$ & Li et al. (2006); Le (2016) \\
\hline SSP1 & $\begin{array}{l}\text { Accounting service firms have helped their suppliers } \\
\text { to improve their product quality }\end{array}$ & Li et al. (2006); Le (2016) \\
\hline SSP3 & $\begin{array}{l}\text { Accounting service firms actively involve their key } \\
\text { suppliers in new product development processes }\end{array}$ & Li et al. (2006); Le (2016) \\
\hline Customer relationship (CR) \\
\hline CR1 & $\begin{array}{l}\text { Accounting service firms frequently interact with } \\
\text { customers to set reliability, responsiveness, and } \\
\text { other standards for them }\end{array}$ & Li et al. (2006); Le (2016) \\
\hline CR2 & $\begin{array}{l}\text { Accounting service firms frequently measure and } \\
\text { evaluate customer satisfaction }\end{array}$ & Li et al. (2006); Le (2016) \\
\hline CR3 & $\begin{array}{l}\text { Accounting service firms frequently determine } \\
\text { future customer expectations }\end{array}$ & Li et al. (2006); Le (2016) \\
\hline CR4 & $\begin{array}{l}\text { Accounting service firms periodically evaluate the } \\
\text { importance of our relationship with their customers }\end{array}$ & Li et al. (2006); Le (2016) \\
\hline ISs1 & $\begin{array}{l}\text { Accounting service firms inform trading partners in } \\
\text { advance of changing needs }\end{array}$ & Li et al. (2006); Le (2016) \\
\hline
\end{tabular}




\section{Evaluation the Supply Chain Management in the Accounting Service Firms in Hanoi}

\begin{tabular}{|l|l|l|}
\hline ISs2 & $\begin{array}{l}\text { Trading partners of accounting service firms share } \\
\text { business knowledge of core business processes with } \\
\text { them }\end{array}$ & Li et al. (2006); Le (2016) \\
\hline ISs3 & $\begin{array}{l}\text { Accounting service firms and their trading partners } \\
\text { exchange information that helps establishment of } \\
\text { business planning }\end{array}$ & Li et al. (2006); Le (2016) \\
\hline ISs4 & $\begin{array}{l}\text { Accounting service firms and their trading partners } \\
\text { keep each other informed about events or changes } \\
\text { that may affect the other partners }\end{array}$ & Li et al. (2006); Le (2016) \\
\hline Level of information quality (IQ) & $\begin{array}{l}\text { Information exchange between accounting service } \\
\text { firms and their trading partners is timely }\end{array}$ & Li et al. (2006); Le (2016) \\
\hline IQ1 & $\begin{array}{l}\text { Information exchange between accounting service } \\
\text { firms and their trading partners is accurate }\end{array}$ & Li et al. (2006); Le (2016) \\
\hline IQ2 & $\begin{array}{l}\text { Information exchange between accounting service } \\
\text { firms and their trading partners is complete }\end{array}$ & Li et al. (2006); Le (2016) \\
\hline IQ3 & $\begin{array}{l}\text { Information exchange between accounting service } \\
\text { firms and their trading partners is adequate }\end{array}$ & Li et al. (2006); Le (2016) \\
\hline IQ4 & $\begin{array}{l}\text { Information exchange between accounting service } \\
\text { firms and their trading partners is reliable }\end{array}$ & Li et al. (2006); Le (2016) \\
\hline
\end{tabular}

SCM in the accounting service firms: The scales are measured by a 5-point Likert scale of 1 which is strongly disagree and 5 is strongly agree.

Analytical techniques: We use Cronbach' Alpha to assess reliability of scales. After cleaning, the collected data entered into the computer via SPSS 22.0 statistical software is 135 questionnaires. After coding and cleaning the data, it is acceptable since all Cronbach's Alpha coefficient of 0.6 or more (Hair et al. 2014).

\section{Research Results}

\subsection{Descriptive Statistics}

Table 2: Respondents by Gender, Job Description

\begin{tabular}{|c|c|c|c|}
\hline & Frequency & Percent & $\begin{array}{l}\text { Cumulative } \\
\text { Percent }\end{array}$ \\
\hline \multicolumn{4}{|l|}{ Gender } \\
\hline Male & 20 & 14.8 & 14.8 \\
\hline Female & 115 & 85.2 & 100.0 \\
\hline \multicolumn{4}{|l|}{ Job description } \\
\hline Business staff & 20 & 14.8 & 14.8 \\
\hline Accounting staff & 40 & 29.6 & 44.4 \\
\hline General accountants & 34 & 25.2 & 69.6 \\
\hline Chief accountants & 17 & 12.6 & 82.2 \\
\hline $\begin{array}{l}\text { Deputy Manager of business } \\
\text { department }\end{array}$ & 14 & 10.4 & 92.6 \\
\hline $\begin{array}{l}\text { Manager of } \quad \text { business } \\
\text { department }\end{array}$ & 10 & 7.4 & 100.0 \\
\hline Total & 135 & 100.0 & \\
\hline
\end{tabular}

Information of data collected is shown in Table 2. It shows that among the 135 respondents, about $14.8 \%$ were male while the remaining 115 (85.2\%) were female. Of these, among the respondents, business staff accounted for $14.8 \%$, accounting staffs accounted for $29.6 \%$, general accounting accounted for $25.2 \%$, chief accountant accounted for $12.6 \%$, deputy manager of business department accounted for $10.4 \%$ and while the remaining $7.4 \%$ or 10 respondents were manager of business department. 
Evaluation the Supply Chain Management in the Accounting Service Firms in Hanoi

Table 3. Descriptive Analysis of Attributes of SCM in the Accounting service firms in Hanoi

\begin{tabular}{|c|c|c|c|c|c|}
\hline & $\mathrm{N}$ & Minimum & Maximum & Mean & Std. Deviation \\
\hline \multicolumn{6}{|c|}{ Strategic supplier partnership (SSP) } \\
\hline SSP1 & 135 & 2.0 & 5.0 & 4.052 & .7563 \\
\hline SSP2 & 135 & 3.0 & 5.0 & 4.267 & . 7351 \\
\hline SSP3 & 135 & 2.0 & 5.0 & 4.200 & .7310 \\
\hline $\begin{array}{ll}\text { Valid } & \mathrm{N} \\
\text { (listwise) } & \\
\end{array}$ & 135 & & & 4.173 & \\
\hline \multicolumn{6}{|c|}{ Customer relationship (CR) } \\
\hline & $\mathrm{N}$ & Minimum & Maximum & Mean & Std. Deviation \\
\hline CR1 & 135 & 2.0 & 5.0 & 4.015 & .7329 \\
\hline CR2 & 135 & 2.0 & 5.0 & 4.044 & .7905 \\
\hline CR3 & 135 & 2.0 & 5.0 & 3.815 & .9157 \\
\hline CR4 & 135 & 2.0 & 5.0 & 3.637 & .8945 \\
\hline $\begin{array}{ll}\text { Valid } & \mathrm{N} \\
\text { (listwise) } & \\
\end{array}$ & 135 & & & 3.878 & \\
\hline \multicolumn{6}{|c|}{ Information sharing (ISs) } \\
\hline ISs1 & 135 & 2.0 & 5.0 & 3.785 & .7369 \\
\hline ISs2 & 135 & 2.0 & 5.0 & 3.622 & . 7004 \\
\hline ISs3 & 135 & 2.0 & 5.0 & 3.650 & .5900 \\
\hline ISs4 & 135 & 3.0 & 5.0 & 3.793 & .7340 \\
\hline $\begin{array}{ll}\text { Valid } & \mathrm{N} \\
\text { (listwise) } & \end{array}$ & 135 & & & 3.713 & \\
\hline \multicolumn{6}{|c|}{ Information quality (IQ) } \\
\hline IQ1 & 135 & 2.0 & 5.0 & 3.726 & .7169 \\
\hline IQ2 & 135 & 2.0 & 5.0 & 3.830 & .7485 \\
\hline IQ3 & 135 & 3.0 & 5.0 & 3.793 & .7238 \\
\hline IQ4 & 135 & 2.0 & 5.0 & 3.840 & .6330 \\
\hline IQ5 & 135 & 3.0 & 5.0 & 3.770 & .5850 \\
\hline $\begin{array}{ll}\text { Valid } & N \\
\text { (listwise) } & \end{array}$ & 135 & & & 3.793 & \\
\hline
\end{tabular}

Table 3 shows that:

Strategic supplier partnership (SSP) including three (3) attributes were quite high with an average of 4.13 compared with the highest of the Likert 5-point scale. All these three (3) attributes were rated at an average of 4.052 or higher.

Customer relationship (CR) including four (4) attributes were quite high with an average of 3.878 compared with the highest of the Likert 5-point scale. All these four (4) attributes were rated at an average of 3.637 or higher.

Information sharing (ISs) including four (4) attributes were quite high with an average of 3.713 compared with the highest of the Likert 5-point scale. All these four (4) attributes were rated at an average of 3.622 or higher.

Information quality (IQ) including five (5) attributes were quite high with an average of 3.793 compared with the highest of the Likert 5-point scale. All these five (5) attributes were rated at an average of 3.793 or higher.

\subsection{Cronbach's Alpha}

SCM in the Accounting service firms in Hanoi has been measured by the Cronbach's Alpha. Results of testing Cronbach's alpha of SCM are presented in Table 4 below. The results also show that 15 attributes of SCM variables have Cronbach's Alpha coefficients that are greater than 0.6, and are less than the common Cronbach's Alpha coefficient; the correlation coefficients of 15 attributes are greater than 0.3. So, 15 attributes of the SCM are statistically significant (Hoang \& Chu, 2008; Hair et al. 2009). IQ4'variable was eliminated because of Cronbach Alpha is greater than the common Cronbach's Alpha coefficient. (Hoang \& Chu, 2008; Hair et al. 2009). 


\section{Evaluation the Supply Chain Management in the Accounting Service Firms in Hanoi}

Table 4. Results of Cronbach's Alpha Testing of Attributes

\begin{tabular}{|c|c|c|c|c|}
\hline & $\begin{array}{l}\text { Scale Mean if } \\
\text { Item Deleted }\end{array}$ & $\begin{array}{l}\text { Scale Variance if } \\
\text { Item Deleted }\end{array}$ & $\begin{array}{l}\text { Corrected Item- } \\
\text { Total Correlation }\end{array}$ & $\begin{array}{l}\text { Cronbach's Alpha if } \\
\text { Item Deleted }\end{array}$ \\
\hline \multicolumn{5}{|c|}{ Strategic supplier partnership (SSP): Cronbach's Alpha: .848 } \\
\hline SSP1 & 8.467 & 1.878 & .646 & .845 \\
\hline SSP2 & 8.252 & 1.772 & .755 & .751 \\
\hline SSP3 & 8.319 & 1.786 & .752 & .754 \\
\hline \multicolumn{5}{|c|}{ Customer relationship (CR): Cronbach's Alpha: .898 } \\
\hline CR1 & 11.496 & 5.595 & .706 & .893 \\
\hline CR2 & 11.467 & 5.012 & .832 & .849 \\
\hline CR3 & 11.696 & 4.721 & .759 & .877 \\
\hline CR4 & 11.874 & 4.633 & .817 & .852 \\
\hline \multicolumn{5}{|c|}{ Information sharing: Cronbach's Alpha: .753 } \\
\hline ISs1 & 11.067 & 2.316 & .692 & .608 \\
\hline ISs2 & 11.230 & 2.462 & .664 & .629 \\
\hline ISs3 & 11.200 & 3.385 & .312 & .752 \\
\hline ISs4 & 11.059 & 2.579 & .549 & .696 \\
\hline \multicolumn{5}{|c|}{ Information quality (IQ) Cronbach's Alpha: .810 } \\
\hline IQ1 & 15.237 & 3.973 & .756 & .720 \\
\hline IQ2 & 15.133 & 3.967 & .711 & .735 \\
\hline IQ3 & 15.170 & 3.993 & .737 & .726 \\
\hline IQ4 & 15.119 & 5.150 & .382 & .831 \\
\hline IQ5 & 15.193 & 5.201 & .414 & .809 \\
\hline
\end{tabular}

\section{Discussions and Implications}

\section{Strategic supplier partnership (SSP)}

There are some typical suppliers of accounting services firms include: enterprises providing accounting software, enterprises providing accounting human resources, enterprises providing office machines (printers, scanners, photocopiers ...), enterprises providing stationery... The relationship between accounting services firms and suppliers is quite close, based on many criteria, including quality factors. For example, for enterprises providing accounting software; quality factors are shown: (i) Save time for accountants, (ii) high accuracy, (iii) easy to use for all accountants, (iv) clear and fast execution, (v) can be linked to the tax declaration system, (vi) good warranty processing...

\section{Customer relationship (CR)}

Accounting service firms and customers jointly sign contracts on the provision of accounting services. The main contents of the contract are the jobs, the number of services, the completion time. In addition, rights and obligations of customers who hire services and accounting service firms are also clearly stated. Thus, the signed contract contributes to improving the responsibility of accounting service firms. Besides, it also helps customers feel secure. Customers always hope that Accounting service firms will fully amd accurately exercise with high quality. Thereby, customers evaluate the quality of services provided by Accountign service firms (Dinh \& Do, 2020).

\section{Information sharing (ISs)}

The information sharing of accounting services firms is shown to both customers and suppliers. However, the level and completeness of each information when sharing is different.

The process of providing accounting services shared by accounting firms to customers and suppliers consists of eight (8) steps (Nguyen et al, 2020):

(i) Receiving customer requests: Customers may request to provide services by phone, email or online request through the website of accounting service firms.

(ii) Survey: The accounting service firms conducts a preliminary survey on the status and characteristics of customers' activities in order to plan service delivery and analyze service charges.

(iii) Preparing quotation documents, negotiating, signing contracts: Accounting service firms send price lists to customers, sign contracts with customers, clearly stating the service content will provide, service fees, staffing services, etc. 


\section{Evaluation the Supply Chain Management in the Accounting Service Firms in Hanoi}

(iv) Service planning: The accounting service firms discuss with its customers the overall and detailed service plan to ensure that the work runs on time with high quality.

(v) Providing services to customers.

(vi) Exchanging, reporting performance results to customers: The accounting service firms discuss with the client about the results of the work and the notes in the providing service process. In the end, the accounting service firms and the client will have meetings to report and agree on overall results.

(vii) Preparing and publishing reports on the results of service provision: The accounting services firms send the customers the results of the service and the management letter.

(viii) Record keeping: Accounting service firms perform the record-keeping scientifically, safely and confidentially according to regulations.

Information quality (IQ)

Customer's demand for accounting services is diverse. Customers have different business lines, so the demand for accounting services also has many differences. Customers expect the accuracy of time for some services like Tax report, Tax return. Customers also expect support on advising, clearly explaining the contents of newly promulgated legal documents such as regulations and circulars, etc. Accounting service firms serve customers quickly and happily, not putting pressure to customer (Dinh \& Do, 2020).

\section{References}

1) Beamon, B. M. (1999). Measuring supply chain performance. International Journal of Operations \& Production Management, 19(3), 275-292.

2) https://doi.org/10.1108/01443579910249714

3) Chen, I.J., \& Paulraj. A. (2004). Towards a Theory of Supply Chain Management. Journal of Operations Management, 22 (2), 119-150. DOI: 10.1016/j.jom.2003.12.007.

4) Chin, T. A., Hamid, A. B. A., Rasli, A., \& Baharun, R. (2012). Adoption of Supply Chain Management in SMEs. Procedia Social and Behavioral Sciences, 65, 614-619. DOI: 10.1016/j.sbspro.2012.11.173.

5) Chuang, M. N., \& Shaw, W. H. (2005). Integration Stages in Supply Chain Management. IEEE Engineering Management Review, 35(2), 80-87.

6) Cigolini, R., Cozzi, M., \& Perona, M. (2004). A New Framework for Supply Chain Management Conceptual Model and Empirical Test. International Journal of Operations \& Production Management 24(1), 7-41. DOI: $10.1108 / 01443570410510979$.

7) Dinh, T. T. L., \& Do, D. T. (2020). Determinants influencing the quality of accounting service: The case of accounting service firms in Hanoi, Vietnam. Management Science Letters, 10 (2020), 675-682.

8) Donlon, J. P. (1996). Maximizing value in the supply chain. Chief Executive, 117, 54-63.

9) Ha, V. H. (2012). Vietnam's textile and garment export value chain - Disadvantages, difficulties and coping measures. Vietnam National University, Hanoi (VNU) Journal of Science (Specialized in economics and business), 28(4), Accessed: http://dl.ueb.vnu.vn/handle/1247/6138. [Vietnamese]

10) Hair, J. F., Black, W. C., Babin, B. J., \& Anderson, R. E. (2009). Multivariate Data Analysis (7th ed.). Upper Saddle River, NJ: Prentice Hall International.

11) Hair, J. F., Henseler, J., Dijkstra, T., Sarstedt, M., Ringle, C., Diamantopoulos, A., Straub, D., Ketchen, D., GTM, H., \& Calantone, R. (2014). Common beliefs and reality about partial least squares: comments on Rönkkö and Evermann. Organizational Research Methods, 17(2), 182-209.

12) Hoang, T., \& Chu, N. M. N. (2008). Analyzing researched data with SPSS (2nd ed.). Ho Chi Minh City, Vietnam: Hong Duc Publishing House. [Vietnamese]

13) Lambert, D. M., Douglas, M., Stock, J. R., \& Ellram, J. M. (1998). Fundamentals of logistics management, Boston, MA: Irwin/McGraw-Hill, chapter 14.

14) Le, T. M. H. (2016). Supply chain management - Solution to increase competitive advantage for small and medium enterprises: The case of Da Nang. Journal of development and economic, 27(10), 94-113. [Vietnamese]

15) Li, S., Ragu-Nathan. B., Ragu-Natha. T. S., \& Subba Rao. S. (2006). The impact of supply chain management practices on competitive advantage and organizational performance. Omega, 34(2), 107-124.

16) Mai, T. H. M. (2013). Vietnam Accounting Services, limitations to overcome, Accounting and Auditing Journal, 13(1), 79. [Vietnamese] 


\section{Evaluation the Supply Chain Management in the Accounting Service Firms in Hanoi}

17) Neely, A. D., Gregory, M., \& Platts, K. (1995). Performance measurement system design A literature review and research agenda. International Journal of Operations \& Production Management, 25(12), 1228-1263.

18) Nguyen, T. N. L., Doan, T. D., \& Do, D. T. (2020). A Study on Job Satisfaction of Accountants in Vietnam. International Journal of Innovation, Creativity and Change. 13(5), 17-36.

19) Sandhu, M.A., Helo, P. \& Kristianto, Y. (2013). Steel supply chain management by simulation modeling. Benchmarking: An International Journal, 20(1). 45-61.

20) Stock, J., \& Boyer, S. (2009). Developing a Consensus Definition of Supply Chain Management: A Qualitative Study. International Journal of Physical Distribution \& Logistics Management, 39, 690-711. http://dx.doi.org/10.1108/09600030910996323

21) Tan, K. C., Kannan, V. R., Handfield, R. B. (1998). Supply chain management: supplier performance and firm performance. International Journal of Purchasing and Materials Management Summer, 34(3), 2-9.

22) Tan, K. C. (2001). A Framework of Supply Chain Management Literature. European Journal of Purchasing \& Supply Management, 7(1), 39-48. DOI: 10.1016/S0969-7012(00)00020-4

23) Yap, L. L., \& Tan, C. L. (2012). The Effect of Service Supply Chain Management Practices on the Public Healthcare Organizational Performance. International Journal of Business and Social Science, 3(16), 216-224.

24) Vaart, T. V. D., \& Donk, D. P. V. (2008). A Critical Review on Survey-Based Research in Supply Chain Integration. International Journal of Production Economics, 111(1), 42-55.

25) DOI: 10.1016/j.ijpe.2006.10.011

26) Vo, T. T. L., \& Nguyen, P. S. (2011). Solution to upgrade the ST5 specialty rice value chain in Soc Trang province. Can Tho University Journal of Science, 27, 25-33. [Vietnamese] 